\title{
An Assessment of the Use of Direct Contact Condensers with Wet Cooling Systems for Utility Steam Power Plants
}

\section{Desikan Bharathan}

Edward Hoo

National Renewable Energy Laboratory

Paul D'Errico

Stone and Webster Engineering

Corporation

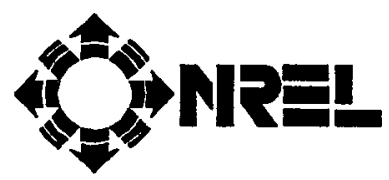

National Renewable Energy Laboratory (formerly the Solar Energy Research Institute) 1617 Cole Boulevard Golden, Colorado 80401-3393

A Division of Midwest Research Institute Operated for the U.S. Department of Energy under Contract No. DE-AC02-83CH10093 


\title{
On September 16, 1991 the Solar Energy Institute was designated a national laboratory, and its name was changed to the National Renewable Energy Laboratory.
}

\section{NOTICE}

This report was prepared as an account of work sponsored by an agency of the United States government. Neither the United States government nor any agency thereof, nor any of their employees, makes any warranty, express or implied, or assumes any legal liability or responsibility for the accuracy, completeness, or usefulness of any information, apparatus, product, or process disclosed, or represents that its use would not infringe privately owned rights. Reference herein to any specific commercial product, process, or service by trade name, trademark, manufacturer, or otherwise does not necessarily constitute or imply its endorsement, recommendation, or favoring by the United States government or any agency thereof. The views and opinions of authors expressed herein do not necessarily state or reflect those of the United States government or any agency thereof.

\author{
Printed in the United States of America \\ Available from: \\ National Technical Information Service \\ U.S. Department of Commerce \\ 5285 Porł Royal Road \\ Springfield, VA22161 \\ Price: Microfiche A01 \\ Printed Copy $\mathrm{AO} 3$
}

Codes are used for pricing all publications. The code is determined by the number of pages in the publication. Information pertaining to the pricing codes can be found in the current issue of the following publications which are generally available in most libraries: Energy Research Abstracts (ERA); Government Reports Announcements and Index (GRA and I); Scientific and Technical Abstract Reports (STAR); and publication NTIS-PR-360 available from NTIS at the above address. 


\section{Table of Contents}

Page

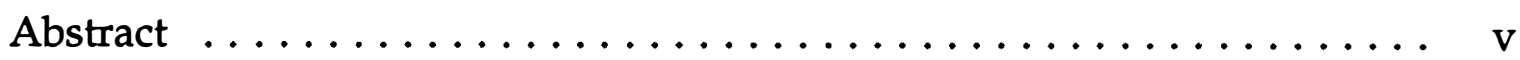

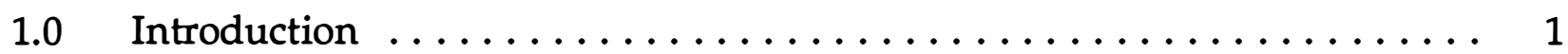

2.0 Background on Surface Condensers $\ldots \ldots \ldots \ldots \ldots \ldots \ldots$

3.0 Description of an Alternative Heat Rejection System ............ 7

3.1 Direct Contact Condenser (DCC) $\ldots \ldots \ldots \ldots \ldots \ldots \ldots \ldots \ldots$

3.2 Plate Heat Exchangers (PHEs) $\ldots \ldots \ldots \ldots \ldots \ldots \ldots \ldots . . \ldots$

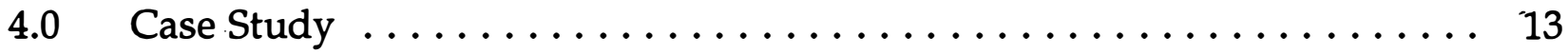

4.1 Performance of the Direct Contact Condenser $\ldots \ldots \ldots \ldots \ldots \ldots$

4.2 Economic Analysis . . . . . . . . . . . . . . . . 23

5.0 Relative Merits of the DCC/PHE System ................ 25

5.1 Operation and Maintenance $\ldots \ldots \ldots \ldots \ldots \ldots \ldots \ldots \ldots \ldots$

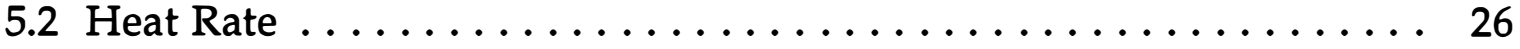

5.3 Cost Reduction ............................ 27

6.0 Conclusions and Recommendations ................... 29

$7.0 \quad$ Acknowledgments $\ldots \ldots \ldots \ldots \ldots \ldots \ldots \ldots \ldots \ldots \ldots \ldots \ldots \ldots \ldots$

$8.0 \quad$ References $\ldots \ldots \ldots \ldots \ldots \ldots \ldots \ldots \ldots \ldots \ldots \ldots \ldots \ldots \ldots \ldots \ldots$ 


\section{List of Figures}

$\underline{\text { Page }}$

1-1 Fossil-fueled conventional steam power cycle schematic diagram ..... 2

3-1 Schematic diagram of an alternative heat-rejection system using a direct contact condenser and multiple plate heat exchangers ........ 8

3-2 Schematic diagram of a two-stage direct contact condenser (DCC) 9

3-3 Relative heat-exchanger cost versus size for PHEs and surface condensers $\ldots \ldots \ldots \ldots \ldots \ldots \ldots \ldots \ldots \ldots \ldots \ldots$

4-1 Power cycle diagram with surface condenser $\ldots \ldots \ldots \ldots \ldots \ldots$

4-2 Power cycle diagram with direct-contact condenser $\ldots \ldots \ldots \ldots \ldots$

4-3 Steam and water temperature variations through the cocurrent stage 19

4-4 Dissolved air concentration and equilibrium levels through

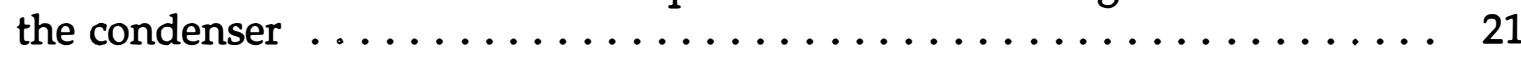

4-5 Steam and water temperature variations through the

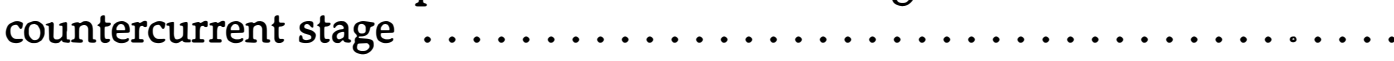

\section{List of Tables}

Page

4-1 Surface condenser design parameters $\quad 14$

4-2 Direct contact condenser design parameters $\ldots \ldots \ldots \ldots \ldots \ldots \ldots . \ldots$

4-3 Comparison of plant condenser and output parameters for systems using a surface condenser and a direct contact condenser . . . . . . . 18

4-4 Relative cost (M\$) of the DCC/PHE system for the case study . . . . . . 24 


\begin{abstract}
Potential use of a direct contact condenser for steam recovery at the turbine exhaust of a utility power plant using a wet cooling system is investigated. To maintain condensate separate from the cooling water, a bank of plate heat exchangers is used. In a case study for a nominal $130-\mathrm{MW}_{\mathrm{e}}$ steam power plant, two heat rejection systems, one using a conventional surface condenser and another using a direct contact condenser together with a set of plate heat exchangers are compared on the basis of their performance, operation and maintenance, and system economics. Despite a higher initial cost for the direct contact system, the advantages it offers suggests that this system is viable both technically and economically.

Key to the improvements the direct contact system offers is a higher equivalent availability for the power system ${ }^{1}$. Reduction of dissolved oxygen and other metallic ions in the condensate, reduced use of chemical scavengers and polishers, and potential elimination of a plant floor are also major benefits of this system. Drawbacks include added plant components and higher initial cost. The potential for long-term cost reduction for the direct contact system is also identified.
\end{abstract}

${ }^{1}$ In a broad sense, the term availability means the fraction of time a generating unit is able to supply power at various capacity levels; equivalent availability refers to this fraction when it is nomalized to the plant's design generating capacity. 


\subsection{Introduction}

Shell-and-tube surface condensers are commonly used in the electric power generation industry. This key component of the power plant performs the following functions:

- transfers the heat rejected by the steam cycle to a heat sink, either a body of water or a cooling tower,

- acts as a barrier between the treated condensate and the cooling water and/or the atmospheric air, and

- concentrates noncondensible gases for efficient removal.

Figure 1-1 illustrates the function of the condenser in a fossil-fueled power plant.

With loss and degradation of any of the surface condenser's functions, the plant's efficiency and availability decrease. Documented evidence from the Electric Power Research Institute (EPRI) and elsewhere suggests the following:

- Problems related to the surface condensers cause plants to suffer up to a $3.8 \%$ loss in equivalent availability resulting in partial load reductions and forced outages for coalfired utility units with capacities of $400 \mathrm{MW}$ and larger. Most of this loss occurs because of fouling of the tubes' inner surfaces. For U.S. fossil plants, a total loss of more than $\$ 1$ billion per year is directly attributable to surface condenser problems [1].

- The condensers' capability to remove noncondensible gases decreases drastically at part loads. As a result, heat rate in the plant rises and condensate with undesirable levels of dissolved oxygen circulates throughout the plant, causing damage to other system components [2].

To remedy these problems, industry (1) replaces commonly used admiralty brass tubes with titanium or AL6X tubes and (2) adds a separate deaeration device downstream of the condenser. These measures double the original equipment costs and cause prolonged outages during repair. Although tubes of stronger alloys may allow increased cooling water velocities to mitigate loss of condenser effectiveness from fouling, higher velocities cause increased pressure losses. Cleaning the tubes is a time-consuming operation that, even when carefully scheduled, results in a significant loss of plant capacity. On-line cleaning systems can be installed for an increase in capital and maintenance costs.

Neither alternative offers a cost-effective, long-term solution to the problems of maintaining a clean heat-transfer surface and efficiently operating a surface condenser throughout a plant's expected 30-year lifetime. While the initial capital cost of a surface condenser is less than $1 \%$ of the power plant cost, its lost availability remains relatively high and is a major concern of the utilities [1]. 


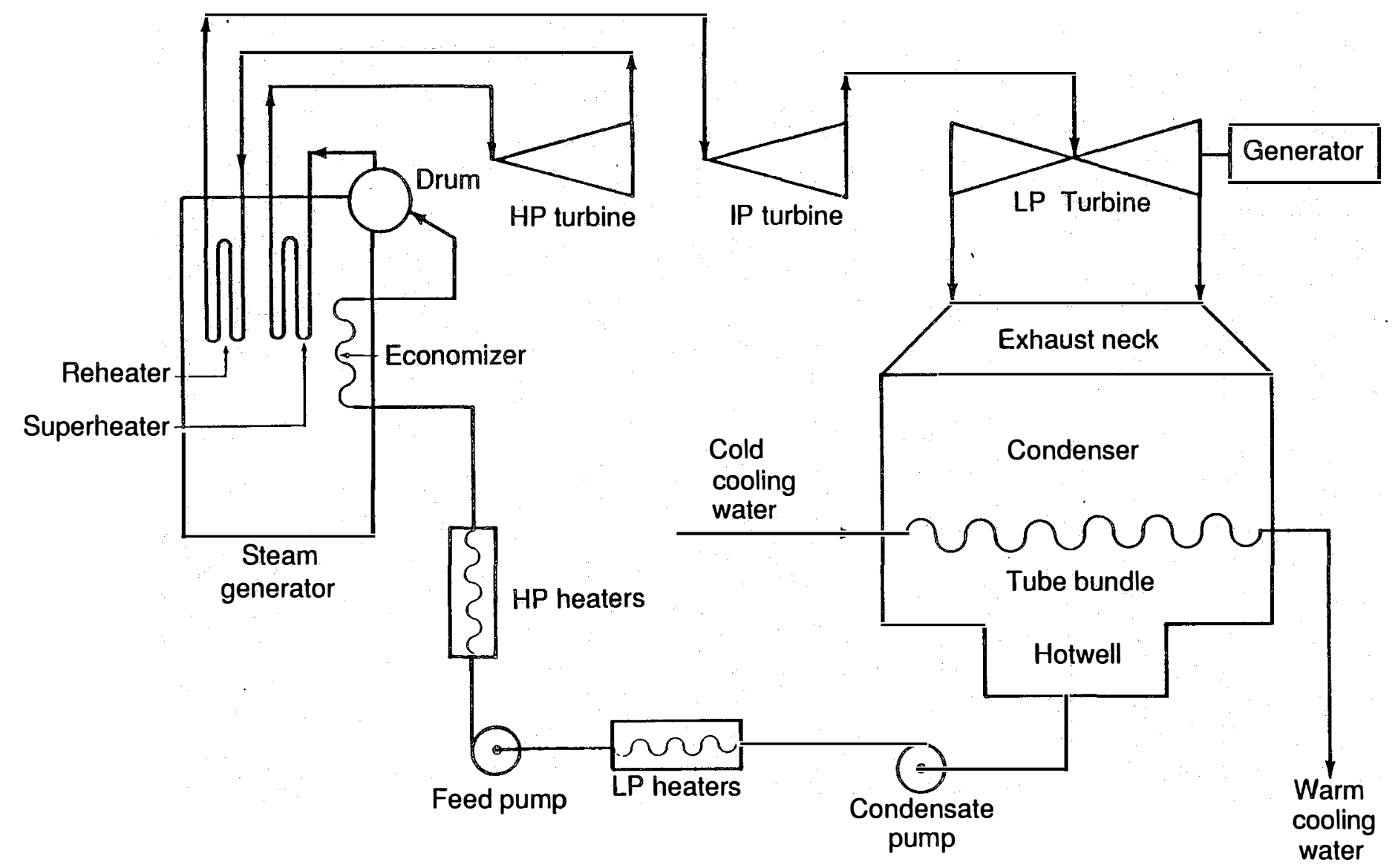

Figure 1-1. Fossil-fueled conventional steam power cycle schematic diagram 
This report outlines ongoing research at the National Renewable Energy Laboratory (NREL) that evaluates alternate heat-rejection schemes which use a direct contact condenser (DCC) in conjunction with plate heat exchangers (PHEs) to improve system reliability and overcome the shortcomings of the shell-and-tube surface condenser. Preliminary results indicate that these schemes are technically and economically viable. However, lack of operating experience with this system prevents an accurate evaluation of its benefits. 
TP-4514 


\subsection{Background on Surface Condensers}

The severity of problems related to surface condensers is exemplified by the inordinate attention they receive from the utility industry. The literature available on condenserrelated issues ranges from detailed surveys on operating experience [3] to workshops and symposia on condensers (for example, see Ref. 4). The majority of the literature focuses on condenser technology to improve plant availability and thermal performance.

Major problems related to surface condensers can be categorized in three areas: fouling, ineffective air removal, and leakage of cooling water.

Fouling occurs on the internal surfaces of the condenser tubes which are difficult to access. A clean condenser fouls rapidly and its thermal performance degrades asymptotically, reaching a cleanliness factor of $60 \%$ [5]. Cleaning of the surfaces must be scheduled frequently during high-fouling seasons, which coincides with the period of peak demand at many sites. During cleaning, split water boxes allow one-half of the condenser to be cleaned while the other half remains functional. About $70 \%$ of the design capacity is maintained. However, this procedure is detrimental to plant heat rate. In addition to reduced plant capacity, a utility may be forced to buy more expensive power from other facilities.

Modern condensers effectively remove the noncondensible gases at design capacities. Such designs are results of extensive research and development on the steam/inert mixture flow around tube bundles. Arranging tubes within a condenser bundle, however, remains an art. A delicate balance must be maintained among steam-side pressure loss, steam partial pressure reduction, condensate inundation, and effective sweeping of the noncondensibles. The bundle arrangement functions effectively at design conditions; but at part loads, the sweeping of noncondensibles becomes less effective, causing air pockets to develop and bind the air in certain regions of the bundle. Symptoms of ineffective air removal are reduced condenser water thermal effectiveness and increased levels of dissolved oxygen in the condensate. For some condensers, EPRI tests indicate that dissolved oxygen levels may reach $60 \mathrm{ppb}$ at $50 \%$ loads. Countermeasures to ineffective air removal include the addition of a deaerator, chemical scavengers, and condensate polishers-all of which increase the plant capital and operating costs.

Potential for leakage of cooling water arises from tube failures caused by a variety of factors: general corrosion, stress corrosion, cracking, crevice corrosion, pitting, galvanic corrosion, condensate grooving, and erosion corrosion. Water leaks, in turn, contaminate the feedwater, leading to its unacceptable chemistry. Procedures for testing leaks range from simple off-line hydrostatic testing to locate major leaks, to tracer gas injection and detection on line, using $\mathrm{SF}_{6}$ to detect leaks as low as one gallon per day [6]. Ongoing, continued, and accurate assessment of the tube wall thickness is necessary for effective condenser life management and for reducing the economic impact of impending failures. 
Countermeasures to in-leakage include:

- Using more expensive tube materials such as titanium,

- Using more elaborate tube-to-tube sheet joining methods, and

- Performing regular and frequent inspections, maintenance, and repair.

To summarize, despite the low initial cost of a surface condenser, its maintenance, operation and failures result in a significant increase in its "cost of ownership" or life-cycle cost. This increased cost results partly because the prime heat-transfer surface is not readily accessible for maintenance, inspection, and repair. 


\subsection{Description of an Alternative Heat Rejection System}

The alternative system shown in Figure 3-1 consists of a direct contact condenser (DCC) to condense the steam, multiple plate heat exchangers (PHEs) to reject the heat to the cooling water, and multiple circulating pumps to transport the condensate between them. Condensate quality water circulates between the DCC and one side of the PHEs. On the other side, the PHEs receive cooling water from an ultimate sink, either a cooling tower or a once-through water reservoir.

The inherent advantage of this configuration is that it provides ready access to the heattransfer surfaces prone to fouling. By simply isolating one PHE from the circuit, it can be serviced while other PHEs are on line, without perceivable loss of plant capacity. Further details of the proposed system follow.

\subsection{Direct Contact Condenser (DCC)}

The DCC is a vacuum vessel containing contact media for enhancing contact between steam and water. DCCs are used with dry cooling systems in a variety of plants throughout the world. The proposed concept here uses the DCC with wet cooling systems and incorporates major advances in design and performance predictions made over the past 10 years at NREL [7].

Turbine exhaust steam is directed downward to come in direct contact with the condensate quality water distributed throughout the DCC. Intimate contact between steam and water is promoted by the contact media, structured packings in this case. Because of the enhanced contact, condensation occurs efficiently and extremely rapidly within a contactor height of about $3 \mathrm{ft}$. The condensate collecting in the hotwell attains a temperature within $1^{\circ} \mathrm{F}$ of the saturation temperature of the incoming steam. Figure 3-2 shows the general arrangement of a DCC with two separate stages for condensation. This two-stage DCC is described in the following sections.

The majority of the incoming steam is condensed in a cocurrent section of the DCC. Noncondensible gases flowing into the condenser along with the incoming steam are enriched in countercurrent flow sections of the DCC that are dispersed throughout the condenser. This DCC technology is not new. A variety of contactors, including sprays, baffles, and random packings, has been used in attempts to achieve intimate contact between the gas and the liquid. Over the past 10 years, researchers at NREL have been developing improved methods to achieve effective condensation with minimal pressure losses in the vapor stream. This research led to the use of structured packings in a DCC to minimize pressure losses and improve condenser effectiveness. NREL has tested DCCs operating at back pressures of less than $0.5 \mathrm{in}$. $\mathrm{Hg}$ and with inert gas concentrations of more than $1 \%$ in the incoming steam [7]. NREL has also developed and validated design and development methodology for steam DCCs and has verified their performance in the field. 


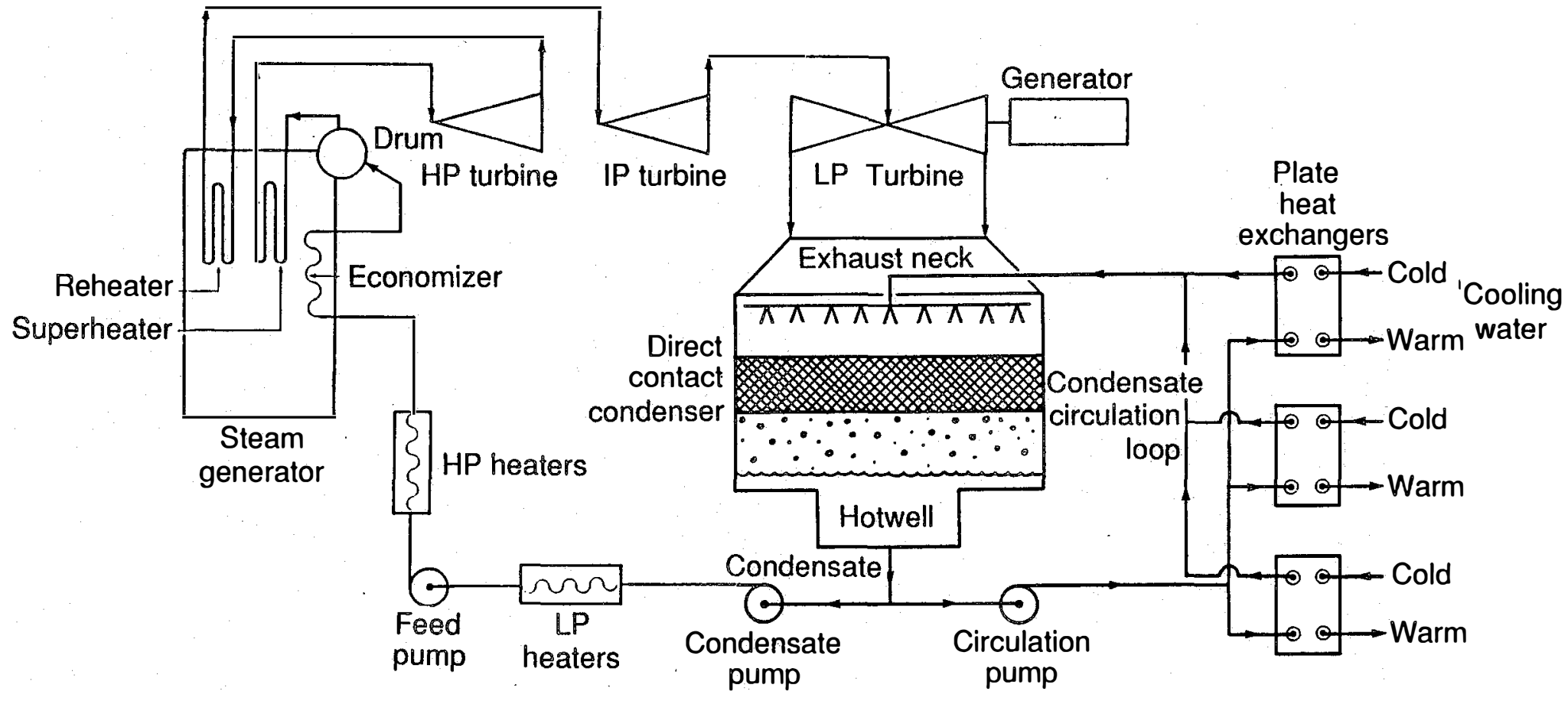

Figure 3-1. Schematic diagram of an alternative heat-rejection system using a direct contact condenser and multiple plate heat exchangers 


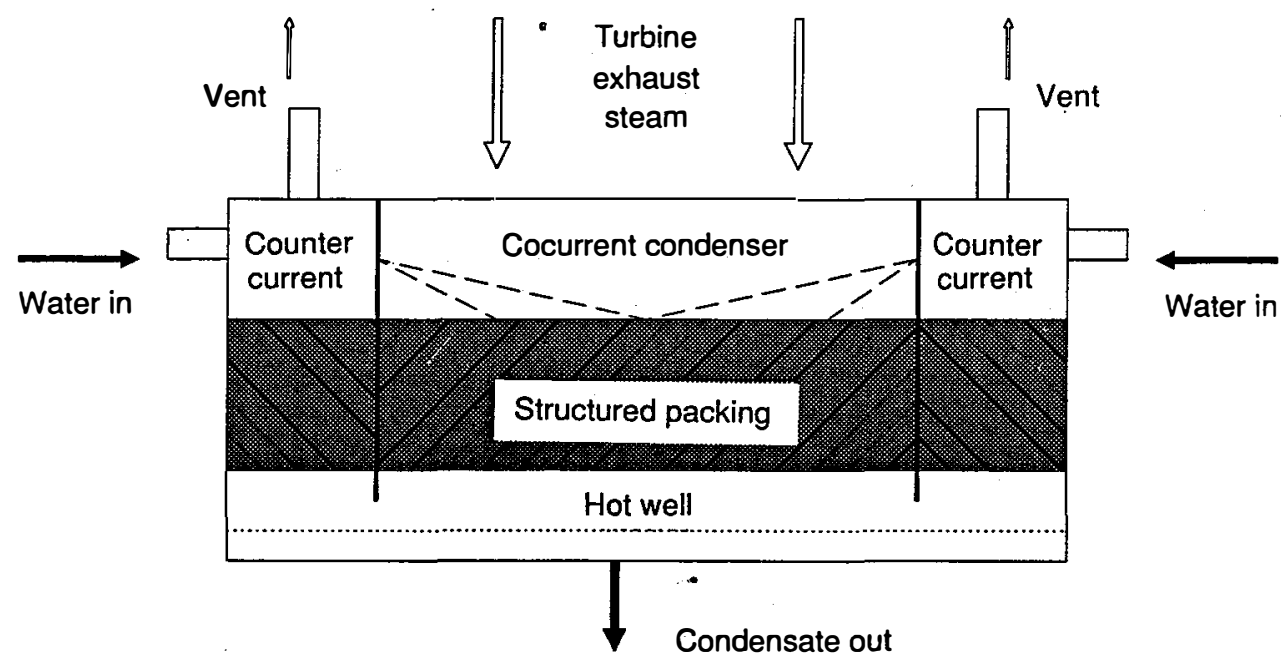

Figure 3-2. Schematic diagram of a two-stage direct contact condenser (DCC)

For utility steam condensation, the condenser back pressure typically ranges over $1 \mathrm{in} . \mathrm{Hg}$, and inert concentrations are around $0.008 \%$ by mass in the incoming steam. For this condition, the majority of the incoming steam will condense in the cocurrent stage of the DCC; the countercurrent stage will concentrate the noncondensibles for effective removal.

The DCC offers these advantages:

- Efficient contact between steam and water results in a terminal temperature difference of less than $1^{\circ} \mathrm{F}$, practically eliminating condensate subcooling at all loads.

- Volumetric heat transfer capacity is large, about $0.4 \mathrm{MMBtu} / \mathrm{h} / \mathrm{ft}^{3}$. In contrast, for the surface condenser at typical utility condenser operating conditions, it is $0.06 \mathrm{MMBtu} / \mathrm{h} / \mathrm{ft}^{3}$.

- Countercurrent stage efficiently enriches the noncondensible gases, thereby aiding in their effective removal. A dissolved oxygen content in the condensate of less than $10 \mathrm{ppb}$ can be maintained at plant load levels down to $10 \%$, as opposed to $100 \mathrm{ppb}$ afforded by the surface condensers.

- Eliminating the thousands of tube penetrations into the vacuum environment significantly decreases the likelihood that cooling water will leak into the power system.

\subsection{Plate Heat Exchangers (PHEs)}

The PHEs are the barriers between the condensate and the cooling water. They can be operated at pressures slightly above atmospheric to eliminate the possibility of air 
in-leakage ${ }^{2}$. Fouling surfaces are easily accessed when PHEs are used instead of a surface condenser. Thus, a higher degree of cleanliness can be maintained throughout their life. The reliable performance of PHEs is well known in many applications industry-wide. Advantages specific to the steam power plant include the following:

- The possibility that cooling water will leak into the condensate stream is significantly reduced because of the effective barrier posed by the heat transfer plates and the favorable pressure gradient between the coolant and cooling water loops.

- Heat transfer can be more cost effective: PHEs offer an overall heat transfer coefficient of up to $1000 \mathrm{Btu} / \mathrm{ft}^{2} \mathrm{~h}^{\circ} \mathrm{F}$ as opposed to up to $600 \mathrm{Btu} / \mathrm{ft}^{2} \mathrm{~h}^{\circ} \mathrm{F}$ typical of surface condensers. The higher heat-transfer coefficient is achieved at the cost of a somewhat increased pressure loss.

- PHEs are capable of economically yielding closer approach temperatures: down to $2^{\circ} \mathrm{F}$, as opposed to the typical $10^{\circ} \mathrm{F}$ for surface condensers.

- Because of increased flow turbulence in the passages, the fouling factor for the PHEs is typically at least five times lower than that for surface condensers.

- Use of PHEs is cost-effective today, and significant potential exists for future cost reductions in large-volume production because of the inherent simplicity of PHE construction.

- Because multiple PHEs are available, the flexibility of system configuration and operation is augmented.

- The maintenance schedule becomes more flexible. PHEs can be isolated and taken apart for cleaning, inspection, and repair purposes, or they may be cleaned in place, without loss of plant capacity.

- Because the PHEs can be isolated for routine cleaning, periodic chlorination of oncethrough cooling water can be eliminated. If necessary, targeted chlorination is also feasible. Either case will help utilities comply with the increased environmental restrictions under which they must operate.

Figure 3-3 illustrates qualitatively the relative cost of the heat-exchanger surface for the PHEs and surface condensers, made of similar material, as a function of the unit size. The PHEs achieve economies of scale at a much smaller unit size than the surface condenser [8]. The fact that small units of PHEs can be fabricated as cheaply as larger units is what makes modularization of the DCC/PHE system attractive.

\footnotetext{
${ }^{2}$ Designs incorporating newly available welded plate PHEs have potential for reduced in-leakage when they are operated under vacuum.
} 
The drawback for the PHEs is that the passages are smaller than those for the surface condenser. To prevent plugging of the cooling water intake manifolds of the PHEs, effective filtering of the water may be required. Biofouling can be handled, however, by targeted chlorination or periodic cleaning.

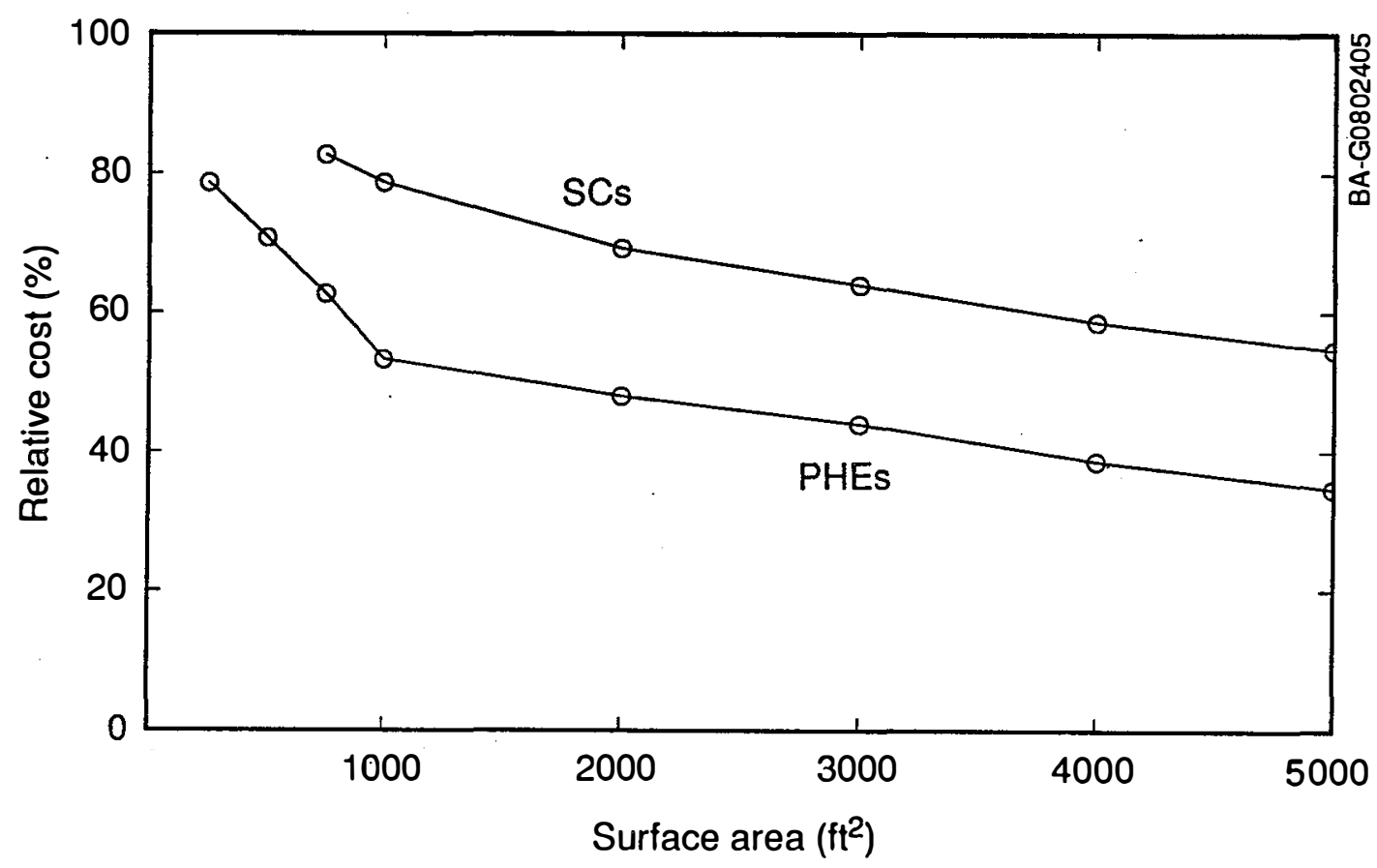

Figure 3-3. Relative heat-exchanger cost versus size for PHEs and surface condensers 
TP-4514 


\subsection{Case Study}

For the purposes of a preliminary technical and economic evaluation of the DCC/ PHE system, a case study was conducted incorporating a DCC in place of a surface condenser for a nominal $133 \mathrm{MW}_{\mathrm{e}}$ steam power plant [9].

The plant uses a tandem compound double-flow turbine with 23-in. last stage blades and a throttle condition of $1800 \mathrm{psig}$ and $1000^{\circ} \mathrm{F}$, and $1000^{\circ} \mathrm{F}$ reheat. The cycle uses six stages of feedwater heating, with a boiler efficiency of $87 \%$. The sink is a mechanical draft wet cooling tower with a design approach of $15^{\circ} \mathrm{F}$ and range of $25^{\circ} \mathrm{F}$. Weather data for Baton Rouge, Louisiana, was used for calculations of performance, with an annual average wetbulb temperature of $61^{\circ} \mathrm{F}$ and a design wet-bulb temperature of $79^{\circ} \mathrm{F}$.

The surface condenser is a two-pass divided water box design, using $7 / 8$ in., 19 BWG, $90 / 10$ copper-nickel tubes. Further details of the surface condenser are summarized in Table 4-1. The design cleanliness was $85 \%$, however, an annual average of $70 \%$ cleanliness was assumed for economic evaluations. The cycle contains a deaerator and a condensate polisher. Figure 4-1 shows the power cycle diagram with the surface condenser.

For the replacement DCC/PHE system, the design point for the DCC was made equal to that of the surface condenser. The PHE's terminal temperature difference was chosen as $8^{\circ} \mathrm{F}$, the same as the surface condenser terminal difference. Because of the absence of any applicable subcooling and low dissolved oxygen in the condensate, the deaerator for this system is replaced by an additional closed feedwater heater. Figure 4-2 shows the power cycle diagram which uses the direct contact condenser. The design parameters for the two stages of the direct contact condenser are shown in Table 4-2.

Cycle heat balances were calculated using well-established methods and procedures [10]. Unit heat rates were based on yearly average ambient conditions. Table 4-3 summarizes key condenser and cycle parameters at three different plant loads. These results were averaged over one year of operation and then used in a follow-up economic analysis.

Surface condenser characteristics were calculated using methods contained in the Heat Exchange Institute (HEI) standards for steam surface condensers [11]. The air removal system was sized according to the HEI standards, resulting in $12.5 \mathrm{scfm}$ venting capacity.

The performance of the DCC was predicted using validated methodologies developed at NREL [7]. Because the analysis of the DCC is generally not well known, the following sections are devoted to the description of the condenser analyses and results.

\subsection{Performance of the Direct Contact Condenser}

The DCC consists of two separate stages-a cocurrent stage in series with a countercurrent stage (see Figure 3-2). In the cocurrent stage, the exhaust steam and the cooling water stream flow downward together. 


\begin{tabular}{|c|c|c|}
\hline \multicolumn{3}{|c|}{ Table 4-1. Surface condenser design parameters } \\
\hline Thernal petrornance neasure & Data: & Units: \\
\hline Condenser pressure & 4.18 & in. $\mathrm{HgA}$ \\
\hline Steam saturation temperature & 127.40 & ${ }^{\circ} \mathrm{F}$ \\
\hline Steam flow rate & 666,480 & $\mathrm{lbm} / \mathrm{h}$ \\
\hline Condenser load & 646 & MMBtu/h \\
\hline Inlet water temperature & 94.00 & ${ }^{\circ} \mathrm{F}$ \\
\hline Outlet water temperature & 119.00 & ${ }^{\circ} \mathrm{F}$ \\
\hline Water volume flow rate & 51,680 & gpm \\
\hline Water side pressure drop & 17.3 & ft. $\mathrm{H}_{2} \mathrm{O}$ \\
\hline Air load & 56.2 & $\mathrm{lb} / \mathrm{h}$ \\
\hline Venting system capacity & 12.5 & acfm \\
\hline \multicolumn{3}{|l|}{ Physical data } \\
\hline Condenser overall length & 40 & $\mathrm{ft}$ \\
\hline Condenser overall width & 14 & $\mathrm{ft}$ \\
\hline Condenser overall height & 23 & $\mathrm{ft}$ \\
\hline \multicolumn{3}{|c|}{ Tube type: $7 / 8 ", 19$ BWG inhibited admiralty tubes } \\
\hline Tube length & 28 & $\mathrm{ft}$ \\
\hline Number of tubes & 9,640 & tubes \\
\hline Total surface area & 61,755 & $\mathrm{ft}^{2}$ \\
\hline \multicolumn{3}{|l|}{ 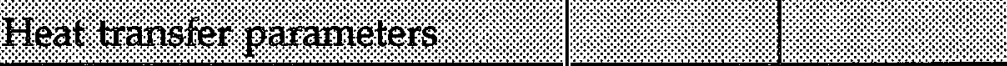 } \\
\hline Log-mean delta-T & 18.11 & ${ }^{\circ} \mathrm{F}$ \\
\hline Overall heat-transfer coeff. & 593 & $\mathrm{Btu} / \mathrm{h} \mathrm{ft}^{2} \mathrm{~F}$ \\
\hline
\end{tabular}

About $95 \%$ of the steam entering the condenser is condensed in this cocurrent stage. The remaining $5 \%$ is routed through the countercurrent stage where the steam flows upward against the falling water stream. Here it condenses further, and the noncondensible gases are concentrated for efficient removal through the venting system. Venting system capacity is the same as that for the surface condenser as recommended by the HEI standards.

The DCC model evaluates the physical properties of the liquid and gaseous streams along the entire length of the condenser. 


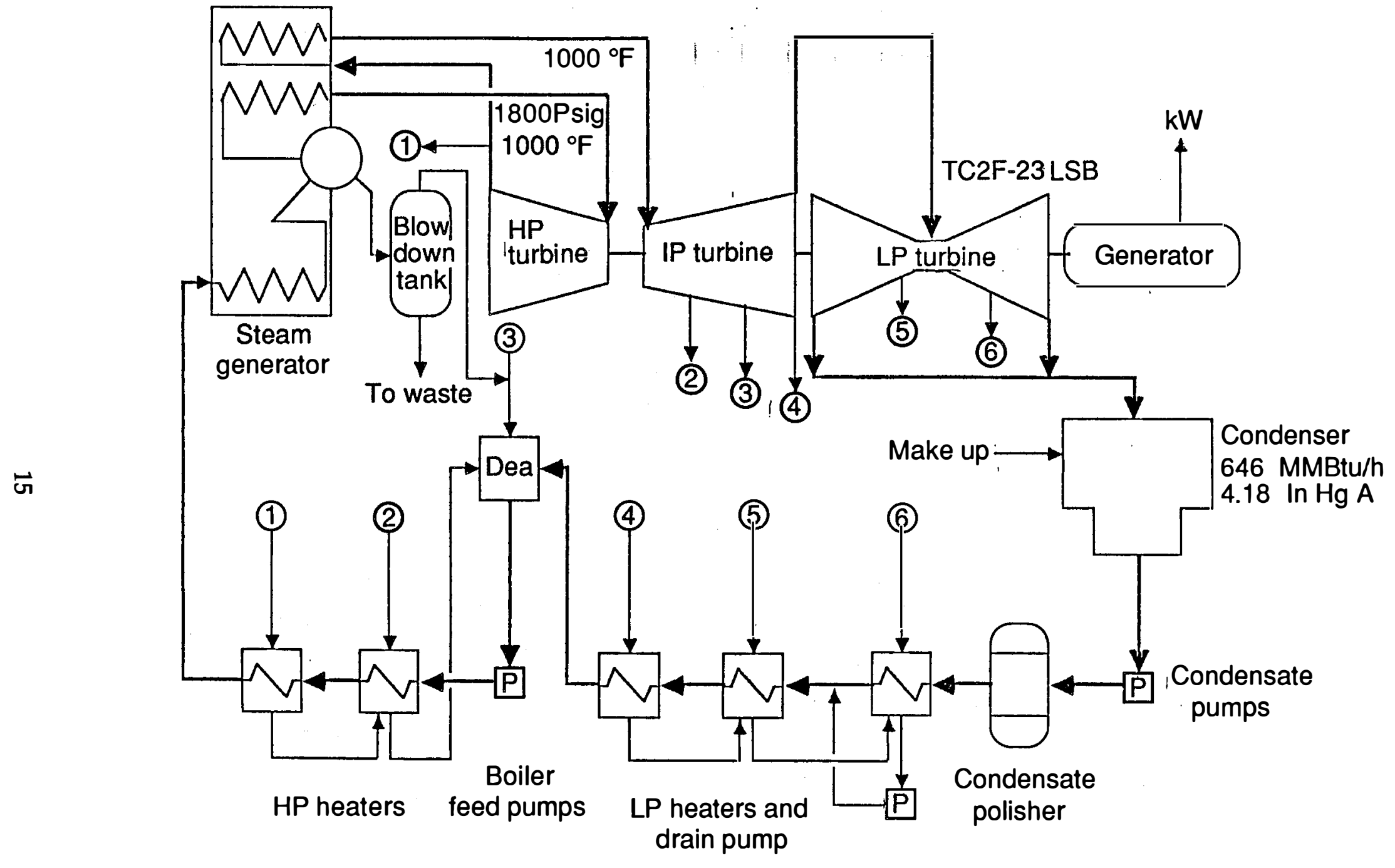

Figure 4-1. Power cycle diagram with surface condenser 


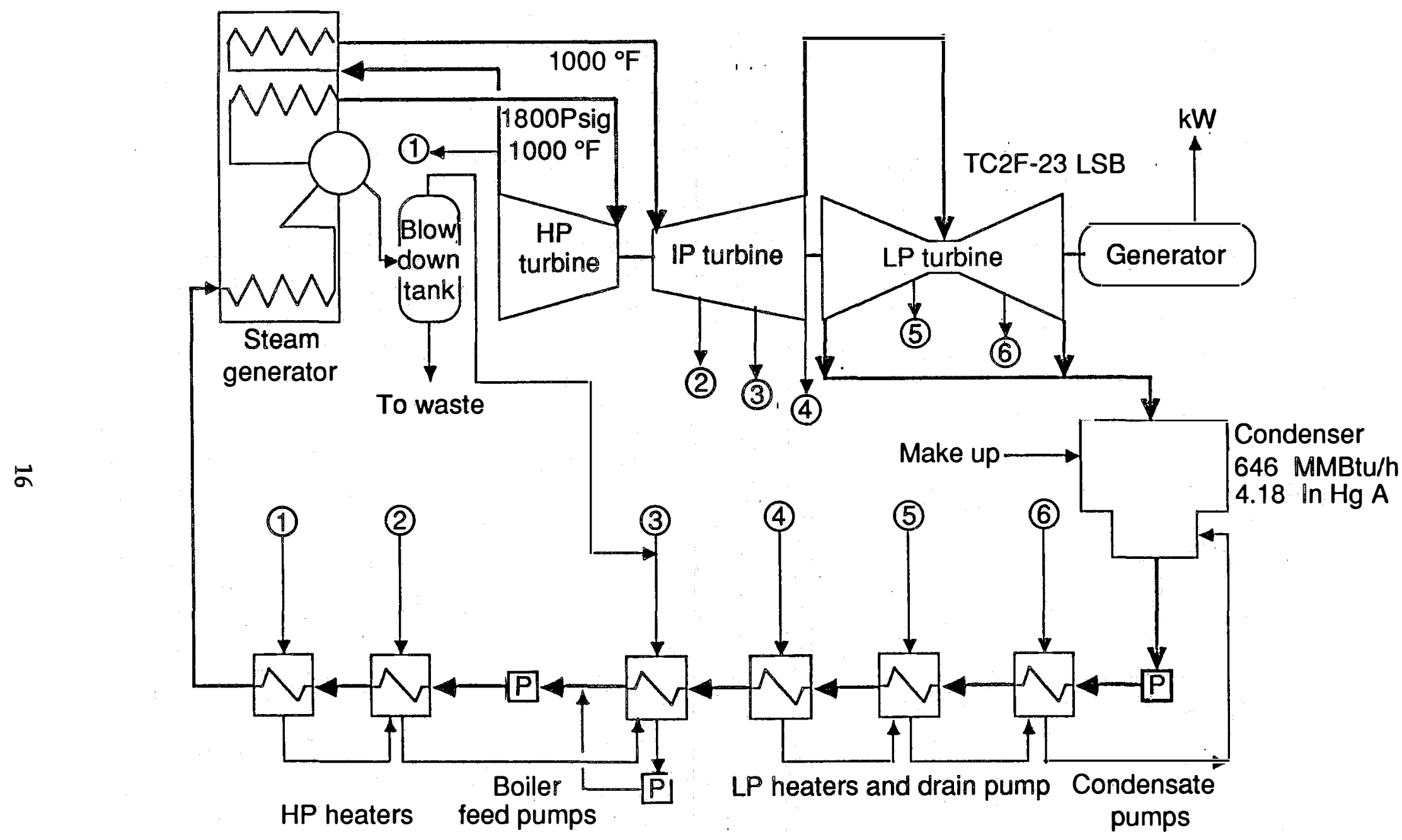




\begin{tabular}{|c|c|c|c|}
\hline Parraneter: & $\begin{array}{l}\text { (er) } \\
\text { current: } \\
\text { Strage: }\end{array}$ & Cormint? & IIII:s \\
\hline Steam loading & 884 & 442 & $\mathrm{lb} / \mathrm{ft}^{2} \mathrm{~h}$ \\
\hline Water loading & 83 & 42 & $\mathrm{gpm} / \mathrm{ft}^{2}$ \\
\hline Inlet steam saturation temperature & 127 & 127 & ${ }^{\circ} \mathrm{F}$ \\
\hline Water inlet temperature & 104 & 104 & ${ }^{\circ} \mathrm{F}$ \\
\hline Water outlet temperature & 126 & 124 & ${ }^{\circ} \mathrm{F}$ \\
\hline Water flow rate & 62,340 & 2,722 & gpm \\
\hline Dissolved air in inlet water & 2 & 2 & $\mathrm{ppb}$ \\
\hline Dissolved air in outlet water & 1.6 & 11.4 & $\mathrm{ppb}$ \\
\hline \multicolumn{4}{|l|}{ 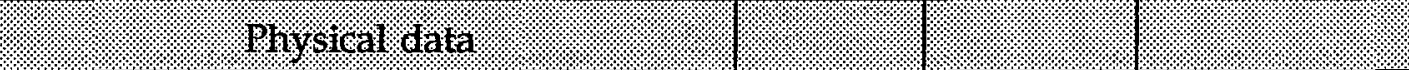 } \\
\hline Planform area & 754 & 65 & $\mathrm{ft}^{2}$ \\
\hline Packing height & 3.5 & 2.5 & $\mathrm{ft}$ \\
\hline Condenser height & 8 & 8 & $\mathrm{ft}$ \\
\hline Packing volume & 2,639 & 164 & $\mathrm{ft}^{3}$ \\
\hline \multicolumn{4}{|l|}{ Teat transfer parameters: } \\
\hline Log-mean delta-T & 6.56 & 9.60 & ${ }^{\circ} \mathrm{F}$ \\
\hline Volumetric heat-transfer coeff. & 39,533 & 17,067 & $\mathrm{Btu} / \mathrm{h} \mathrm{ft^{3 }}{ }^{\circ} \mathrm{F}$ \\
\hline
\end{tabular}

*Condenser pressure, load, air load, and venting capacity are the same as shown for the surface condenser in Table 4-1. 


\begin{tabular}{|c|c|c|c|c|c|c|}
\hline \multicolumn{7}{|c|}{$\begin{array}{l}\text { Table 4-3. Comparison of plant condenser and output parameters for } \\
\text { systems using a surface condenser and a direct contact condenser }\end{array}$} \\
\hline \multirow[t]{2}{*}{$\begin{array}{l}\text { Plant } \\
\text { load } \\
(\%)\end{array}$} & \multicolumn{2}{|c|}{$\begin{array}{l}\text { Condenser back } \\
\text { pressure } \\
\text { (in. Hg) }\end{array}$} & \multicolumn{2}{|c|}{$\begin{array}{l}\text { Net plant output } \\
(\mathrm{kW})\end{array}$} & \multicolumn{2}{|c|}{$\begin{array}{l}\text { Net unit heat rate } \\
(\mathrm{Btu} / \mathrm{kWh})\end{array}$} \\
\hline & $\begin{array}{l}\text { Surface } \\
\text { condenser }\end{array}$ & corntret : & $\begin{array}{l}\text { Surface } \\
\text { condenser }\end{array}$ & $\begin{array}{l}\text { Direet: } \\
\text { contract: }\end{array}$ & $\begin{array}{l}\text { Surface } \\
\text { condenser }\end{array}$ & 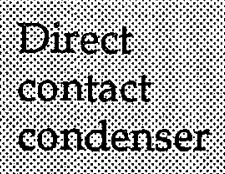 \\
\hline 100 & 3.56 & 3.18 & 125,234 & 125,713 & 10,113 & 10.074 \\
\hline 75 & 2.57 & 2.32 & 96,626 & $967 / 36$ & 10,230 & 19.218 \\
\hline 50 & 1.77 & 1.65 & 63,600 & 63.838 & 10,813 & 10.857 \\
\hline
\end{tabular}

A detailed description of the model and numerical procedures may be found in Ref. 7 . The model was used to predict the behavior of the condenser stages for this case study.

For the cocurrent stage, the temperatures of the steam and cooling water along the stage length are shown in Figure 4-3. Also shown are the gas-liquid interface temperature and the saturation temperature of the steam-inert mixture. The water temperature rises rapidly as it travels down through the condenser due to progressive steam condensation.

In the accompanying expanded view, the temperature of the interface starts out at the initial steam saturation temperature. This occurs because the major resistance to heat transfer resistance lies initially on the water side of the interface. As the steam condenses, however, the proportion of noncondensibles in the steam/air mixture increases; accumulating noncondensibles at this interface impedes the transport of steam to it, thus slowing the rate of condensation. At the bottom of the cocurrent stage, the major resistance to heat transfer shifts to the vapor side,

For the steam/air mixture, the mass transfer decreases the saturation pressure of the steam faster than the corresponding decrease in its temperature because of the accompanying heat transfer. As a result, the steam/air mixture becomes superheated as the condensation proceeds.

A key issue for the utility condensers is the level of dissolved oxygen in the condensate. The present condenser model treats air as a single gas; components such as oxygen and nitrogen are not individually tracked. In general, dissolved oxygen levels are typically one third that of the overall dissolved air levels. 


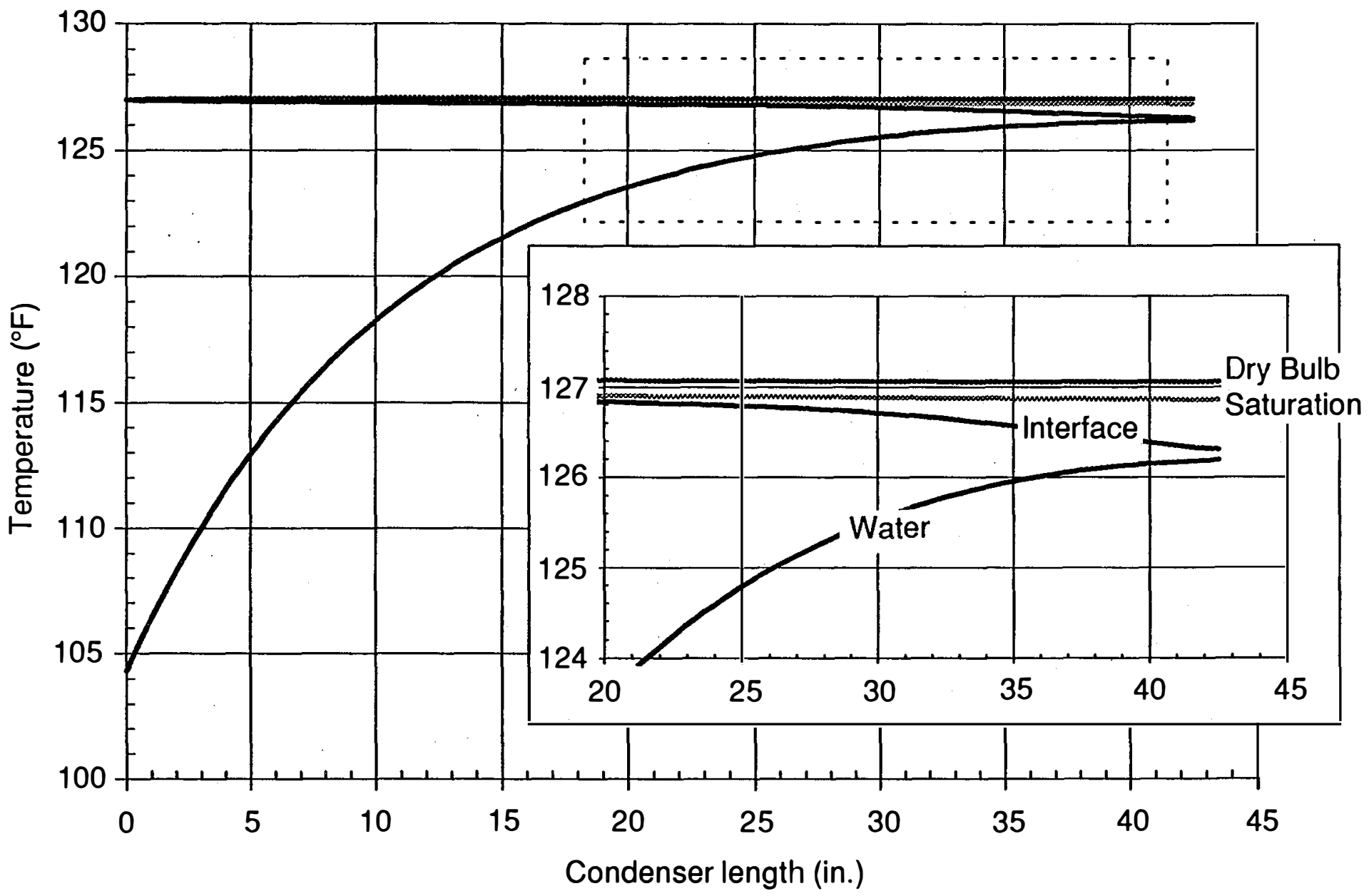

Figure 4-3. Steam and water temperature variations through the cocurrent stage 
Figure 4-4 displays the level of dissolved air in the cooling water in parts per billion as a function of distance along the cocurrent stage of the condenser. This figure also shows its equilibrium levels, based on Henry's law, which are functions of the air partial pressure in the steam/air mixture and the water temperature. At the entrance to the condenser, the equilibrium level is well below the dissolved air in the incoming cooling water, because little air is contained in the incoming steam and, correspondingly, there is very low partial pressure. As a result, air evolves out of solution from the cooling water into the steam/air mixture. As the steam condenses, however, the proportion of air in the gas mixture begins to increase, resulting in a rapid rise in the equilibrium values. At approximately $70 \%$ down the length of this cocurrent stage, the equilibrium values increase beyond the actual dissolved air level in the water. Consequently, the transport of air now reverses and air begins to be absorbed into solution.

Near the bottom of the cocurrent condenser, the temperature difference between the steam/air mixture and the cooling water is relatively small. The rate of condensation slows considerably and, as a result, the rate of increase in the air partial pressure decreases. This causes the rate of increase in the equilibrium values to taper off near the bottom, as shown in Figure 4-4. At the exit from the cocurrent stage, the cooling water has a dissolved air concentration of $1.7 \mathrm{ppb}$ and the noncondensibles account for nearly $0.2 \%$ of the mass of the steam/air mixture.

When the steam/air mixture leaves the cocurrent stage, it contains less than $5 \%$ of the steam that first entered the condenser. This mixture is now routed into the countercurrent stage, where the majority of the remaining steam will be condensed; the noncondensibles will also be concentrated for efficient removal.

The steam/air mixture travels vertically upward through this stage, contrary to the flow of cooling water. The temperature distribution of the mixture and the cooling water along the length of the countercurrent stage is shown in Figure 4-5. As the mixture enters the bottom of this stage, the steam condenses nearly isothermally until about 4 in. below the top of this stage. At this point, the resistance to the transport of steam to the gas/liquid interface increases significantly because of the high levels of noncondensibles in the mixture. The noncondensibles make up $27 \%$ of the mixture's mass at the top of this stage. Near the top of this stage, steam condensation is accompanied by rapid, sensible cooling of the mixture as it encounters the coldest water near the top of this stage.

As in the cocurrent stage, the high levels of noncondensibles tend to insulate the gas/liquid interface from the steam. As a result, the interface temperature at the top of this stage is nearly the water temperature.

Near the bottom, however, the relatively low levels of noncondensibles allow the water-side resistance to dominate the heat transfer. As a result, the interface temperature is close to that of the steam/air mixture. 


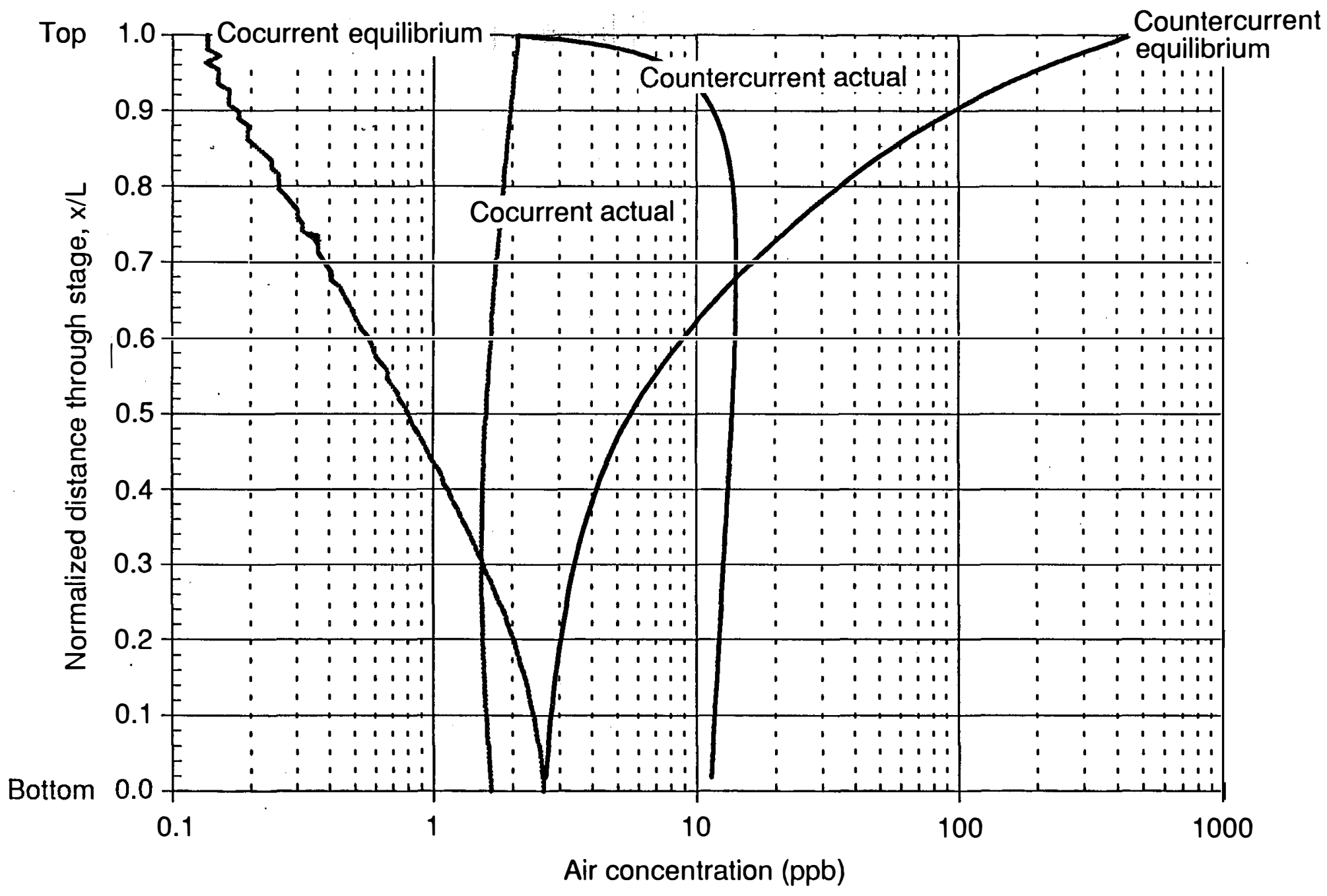

Figure 4-4. Dissolved air concentration and equilibrium levels through the condenser 


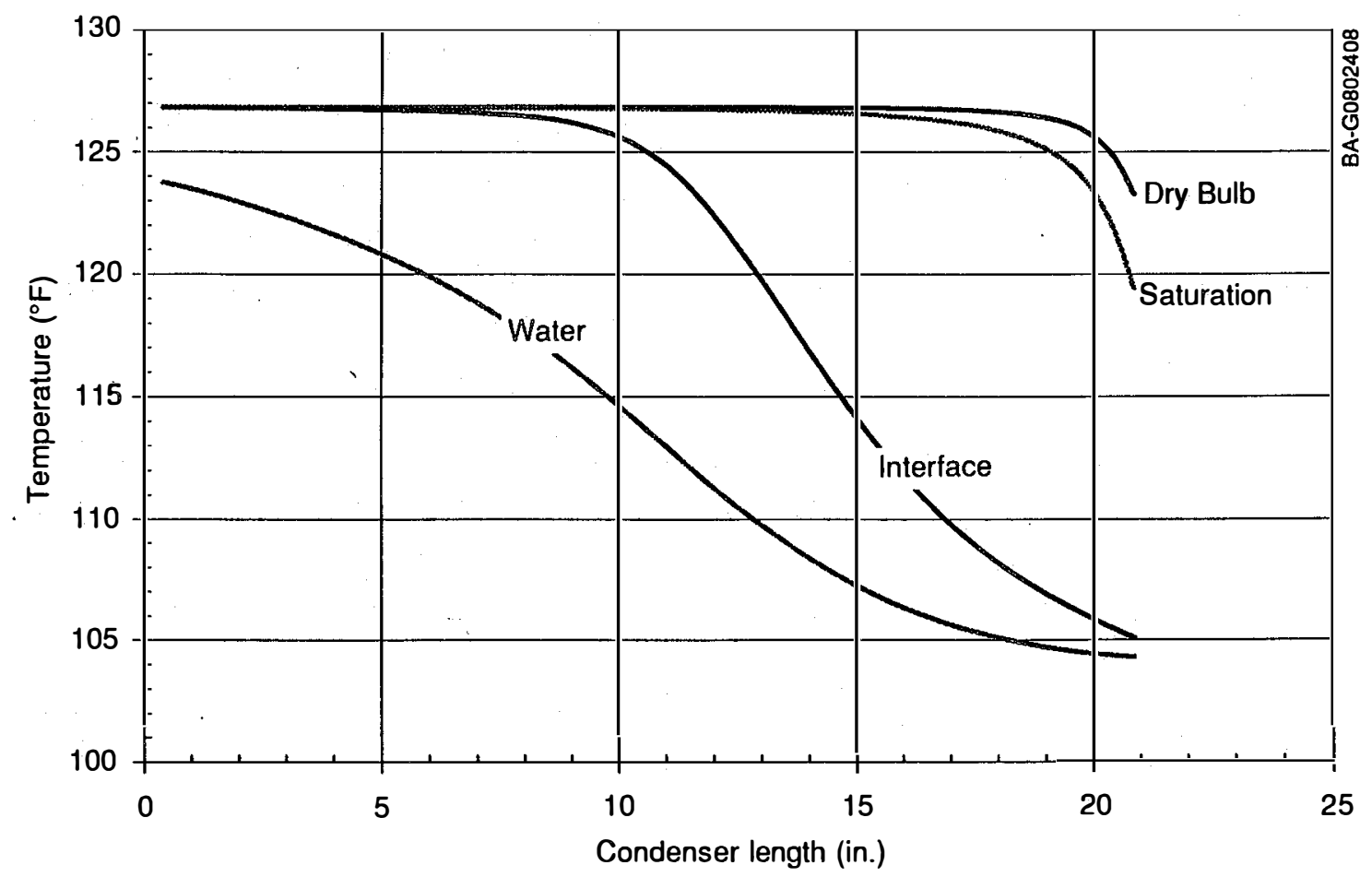

Figure 4-5. Steam and water temperature variations through the countercurrent stage 
The level of dissolved air in the cooling water of this stage, along with the equilibrium value are also displayed in Figure 4-4 as a function of distance along this stage. Near the top of this stage, the equilibrium level reaches its highest value. This is due to the high level of noncondensibles in the steam/air mixture combined with the cold incoming cooling water. The large difference between the equilibrium value and the actual dissolved air level results in a dramatic increase in the dissolved air level. This happens because the air is transported from the gas mixture into solution. As the cooling water travels down through this stage, it encounters lower and lower levels of noncondensibles in the mixture. It also warms as steam condenses. Consequently, the equilibrium values decrease rapidly in the direction of cooling water flow. At approximately $30 \%$ below the top of the countercurrent stage, the equilibrium value falls below the dissolved air level. The transport of air reverses, as the air now evolves from solution until the water exits from the bottom of this stage. Water at the bottom of the countercurrent stage has a dissolved air level of just over $11 \mathrm{ppb}$.

Water streams from the cocurrent and countercurrent stages accumulate in a common hotwell at the bottom of the condenser. Mixing the two streams results in a final dissolved air concentration of $2.1 \mathrm{ppb}$ in the condensate (consistent with the incoming level of the recirculating cold water). A portion of the water in the hotwell is pumped to the feedwater train, and the remainder is pumped to the PHEs for heat rejection to the circulating water and the cooling tower. From the PHEs, the water is pumped back to the top of the condenser, where it is distributed again over the cocurrent and countercurrent stages.

Dissolved air levels achieved with a DCC are extremely low. The dissolved oxygen levels in the condensate can be expected to stay well below $10 \mathrm{ppb}$ at plant loads down to $10 \%$. Low dissolved oxygen level reduces general corrosion throughout the plant. Lower concentrations can be expected for other dissolved gases as well, such as carbon dioxide.

\subsection{Economic Analysis}

A preliminary economic analysis estimated the capital costs for the DCC/PHE system and that for a surface condenser. Potential payback period was also estimated. The incremental cost for the DCC/PHE was assessed at nominally $\$ 13 / \mathrm{kW}_{\mathrm{e}}$ for the plant under consideration [9]. Table 4-4 summarizes the relative costs of the DCC/PHE system for the example studied. Cost reductions resulting from eliminating a floor of plant height were not taken into account. Economic credits for possible reductions in blowdown and chemical use were not assessed.

Using various assumptions about the potential for increased plant equivalent availability, payback periods were estimated based on the present value, assuming typical costs for replacement energy. With a $2 \%$ improvement in the availability, the payback period varied from 9 to 18 years. With a 3\% improvement, the payback period varied from 6 to 10 years. In all cases, the system paid for itself in less than 35 years, the assumed economic life of the plant. 
Within the framework of the analysis, the economic viability for the DCC/PHE system exists. The real advantage of the proposed system is the potential for higher plant availability. For utilities or industrial plant owners that place a higher value on availability, the economic benefit would be greater than noted above. If the increased availability for the DCC/PHE system can be demonstrated, this system can become an economically viable alternative to surface condensers. Additionally, use of this system reduces discharges of hazardous wastes and their environmental impacts as discussed elsewhere.

\begin{tabular}{|c|c|c|}
\hline \multicolumn{3}{|c|}{$\begin{array}{l}\text { Table 4-4. Relative cost (M\$) of the DCC/PHE } \\
\text { system for the case study }\end{array}$} \\
\hline Cost category & $\begin{array}{l}\text { Surface } \\
\text { condenser }\end{array}$ & : \\
\hline Investment & Base & 3.952 \\
\hline Plant size adjustment & Base & 0.836 \\
\hline Capitalized fuel & Base & 9.0 .317 \\
\hline Availability & Base & .9 .947 \\
\hline Height reduction & Base & IIIsessed \\
\hline $\begin{array}{l}\text { Reduced } \\
\text { environmental } \\
\text { discharges }\end{array}$ & Base & :assessec \\
\hline Total & Base & 2.2148 \\
\hline
\end{tabular}




\subsection{Relative Merits of the DCC/PHE System}

Advantages of the DCC/PHE system can be broadly categorized into three areas: (1) operation and maintenance, (2) heat rate and (3) cost reduction.

\subsection{Operation and Maintenance}

The DCC eliminates any air binding problems.

In a surface condenser, the steam flows in crossflow over horizontal tubes carrying the cooling water. The crossflow geometry introduces temperature gradients in three dimensions, causing the steam to distribute poorly. At part loads, steam is diverted preferentially to colder regions of the condenser tubes. This diversion results in air pockets and air binding.

In a DCC, the steam flows either in line with or counter to the coolant. The temperature of the water in planes perpendicular to the steam flow remains uniform, thus avoiding short circuiting of the steam to colder regions. Even steam distribution is maintained, even at part loads, by effectively using the cooling water.

The DCC/PHE system reduces potential for cooling water in-leakage.

In a shell-and-tube condenser, a variety of corrosion mechanisms at thousands of tubeto-tube-sheet joints increases the likelihood for loss of condenser vacuum integrity and cooling water in-leakage [1]. Locating and plugging the leaks is a time-consuming and expensive process, which also results in loss of plant capacity.

In a DCC, such joints are significantly reduced, thus diminishing the probability of leaks. The PHEs can be operated at loop pressures above those of the cooling water to prevent any in-leakage. Should PHEs require repair, an individual PHE can be isolated without losing plant capacity.

The DCC/PHE system offers better control of the dissolved oxygen in the condensate.

In surface condensers, the dissolved oxygen level in the condensate rises rapidly at loads below $50 \%$ [2]. Adding chemical scavengers, a widely used practice, controls this oxygen level. Subcooled condensate in a surface condenser possesses higher solubility of dissolved oxygen. Circulation of condensate with high oxygen levels contributes to failures throughout the system, including steam generator and turbine failures.

The countercurrent portion of the DCC offers the most effective means to remove air from the condenser. Detailed analyses of the oxygen transfer process (between the steam and the condensate) indicate that a dissolved oxygen level of less than $10 \mathrm{ppb}$ can be maintained at loads down to $10 \%$ for a $100 \mathrm{MW}_{\mathrm{e}}$ plant. Such effective removal of air reduces the requirement for chemical scavengers and blowdown. The DCC totally eliminates the possibility of condensate subcooling, thus avoiding increased dissolved oxygen 
solubility. Effective control of the dissolved oxygen can prolong the life of the entire plant.

The DCC/PHE system offers improved plant availability.

Fouling, a major cause of lost equivalent availability for the surface condenser, is addressed quite effectively by the modular set of PHEs, which can be kept cleaner. Scheduling cleaning of surface condenser is more critical because plant capacity must often be reduced. However, scheduling cleaning of an individual PHE is trivial because no loss of plant capacity may be necessary. With fewer DCC/PHE system vacuum penetrations, the overall equivalent availability of the condenser increases substantially.

The DCC/PHE system favorably affects availability of other plant components.

Improved condensate chemistry with less dissolved oxygen, as well as carbon dioxide levels, reduces corrosion of copper and iron parts throughout the plant. Use of a condensate polisher may be reduced or even eliminated. Reduced potential for cooling water in-leakage may noticeably improve the life and reliability of the steam generator and turbine. Blowdown requirements for the plant may also be reduced.

\subsection{Heat Rate}

Increased cleanliness made possible by the DCC/PHE system improves plant heat rate.

The passages of the PHE are convoluted, causing a high degree of turbulence in the coolant and thus reducing the susceptibility for fouling. The PHEs can be designed to maintain a higher degree of cleanliness than the straight tubes of the surface condenser [8]. For the DCC/PHE system, despite the increased pumping power, a heat rate improvement, averaged over the year, of approximately $6 \mathrm{Btu} / \mathrm{kWh}$ was projected in a case study.

Total elimination of condensate subcooling at all loads and at all weather conditions in a DCC/PHE system improves system heat rate.

Some surface condensers, multizone condensers in particular, are prone to subcooling at part loads because of air binding and low cooling water temperatures. To remedy subcooling, a portion of the warm cooling water is recirculated through the condenser. However, because a minimum water velocity of $4.5 \mathrm{ft} / \mathrm{s}$ in the tubes is recommended to control fouling, total elimination of subcooling is not possible.

The DCC cannot subcool the condensate. Elimination of subcooling may improve the heat rate by 10 to $100 \mathrm{Btu} / \mathrm{kWh}$. At low cooling water temperatures, cooling water intake can be reduced and some of the PHEs taken out of service, possibly resulting in reduced auxiliary power requirements (turbine size dependant). Lower cooling water flow and pumping requirements improve the part load heat rate. 
The DCC/PHE system improves part load and cycling capacity.

Operating a surface condenser at lower loads is hindered by higher than acceptable dissolved oxygen levels in the condensate. Part load operation may be inefficient because higher-than-needed cooling water is circulated to control fouling. Neither of these two limitations affect the DCC/PHE performance.

\subsection{Cost Reduction}

The DCC/PHE system significantly reduces condenser height and thus plant height.

The surface condenser tube bundle configuration and tube length limitations substantially affect the turbine building height and the plant cost [12]. Surface condenser height considerations will affect its bundle type, size, and arrangement. The DCC, however, requires a contactor height of less than $3 \mathrm{ft}$. DCC height, including the water distribution manifolds and diffusers below the turbine exhaust, can be kept within the typical height of one plant floor. Thus, it may be possible to reduce the turbine pedestal height and perhaps eliminate an entire floor from the plant, resulting in substantial savings in capital cost. Plant size and consequently the condenser heat load affects the planform area of the DCC, but not the height of the fill.

The DCC/PHE system can reduce or eliminate auxiliary equipment and chemical use.

Makeup water can be directly introduced into the countercurrent region of the DCC. The DCC acts as an effective deaerator, eliminating the need for a separate feedwater deaerator and its support structure. Because of effective oxygen and carbon dioxide removal, need for a polisher may be reduced or eliminated. Chemical additives for control of oxygen in the condensate may be reduced. Blowdown requirements and, consequently, makeup water requirements may also be reduced. Because the PHEs are modular, targeted chlorination to control biofouling becomes attractive, if necessary. Chlorination is reduced thus decreasing its discharge to the environment.

The design process for a DCC/PHE system is simpler.

The design of a surface condenser is complicated by crossflow of the coolant, requiring three-dimensional modeling capabilities [13]. The tube bundle layout, optimized for design conditions, does not provide optimum performance at part loads. Because of the cocurrent and countercurrent flow within the DCC, modeling in one dimension is sufficient for design purposes. The simplification of the design process provides greater opportunities for optimizing the overall plant performance. (Because of the uniform water and steam flows at any condenser cross section, the performance of the DCC improves with decreasing condenser loads.) 
The DCC/PHE system offers potential long-term cost reduction.

Current costs for the surface condenser per unit of heat-transfer area are typically $\$ 10 / \mathrm{ft}^{2}$ for admiralty and $\$ 20 / \mathrm{ft}^{2}$ for titanium or other stainless alloys. The labor-intensive manufacturing process for the surface condenser offers little potential for long-term cost reduction. The current costs for the PHE per unit of heat-transfer area are comparable to costs for a surface condenser made of similar materials. However, the manufacturing of the PHE can be automated, potentially reducing costs of large-volume production by as much as $50 \%$. For the DCC, it is difficult to assess with any certainty the potential for cost reduction because of inadequate market data.

The DCC/PHE system, however, comes with certain drawbacks.

- Because heat rejection occurs in two stages, the driving temperature potential for the heat exchange or logarithmic temperature difference for the PHE is diminished, requiring about $30 \%$ more heat-transfer area than the surface condenser needs.

- The pump-around loop requires a condensate circulating pump, plumbing, water distribution manifolds, and isolating valves for the PHEs. When the condensate side of the PHE is operated at higher than atmospheric pressure, to reduce auxiliary pumping power, a hydraulic turbine should be used to recover the excess head of water in the circulating loop. This turbine adds cost to the system.

- Adequate filtration of the cooling water stream may be required to prevent plugging of passages and inlet manifolds of the PHEs. These may be readily accessible strainers placed adjacent to the cooling water intake ports of the PHEs. Such strainers would be large and expensive and may offset some of the maintenance gains for this system.

- The increase in auxiliary power for the condensate loop results in a small detriment on the plant heat rate.

It appears that the potential gains of the DCC/PHE system outweigh its drawbacks. Without adequate operating experience in a utility environment, however, it is difficult to make a final determination. 


\subsection{Conclusions and Recommendations}

Technically, it is feasible to use a DCC with multiple PHEs for heat rejection in a steam power plant using a wet cooling system. The economic viability of the proposed system is also attractive.

Initial rough cost estimates performed for a nominal $130-\mathrm{MW}_{\mathrm{e}}$ plant yielded an incremental capital cost for the DCC/PHE system of about $\$ 13 / \mathrm{kW}$ of power system capacity. This increment represents less than a 1\% increase in system cost. An averaged net heat rate improvement of approximately $6 \mathrm{Btu} / \mathrm{kWh}$ over that for the system with a surface condenser was projected. An improved equivalent availability of between $1 \%$ to $3 \%$ was estimated. These estimates were done for a retrofit without assuming any cost benefits from reduced plant height or reduced chemical and auxiliary equipment use.

In simple terms, a $2 \%$ improvement on availability resulting from less than $1 \%$ increment in the capital cost is economically attractive.

The proposed alternative system is also environmentally more attractive because of the reduced blowdown and makeup requirements, reduced use of chemical scavengers and polishers, and potential reduction or elimination of chlorination. This system can help meet increasingly stringent chlorination limitations proposed by the Environmental Protection Agency (EPA).

Considering the relative operational and maintenance issues associated with the surface condensers, the DCC/PHE system offers a viable alternative to conventional surface condensers.

In order for utilities to consider such systems, however, an adequately large pilot system must be built and operated. Detailed measurements must be made to assess all aspects of the system performance to provide meaningful measures of the relative merits of the DCC/PHE system when compared to the surface condenser. Sufficient operational experience must also be gained to prevent unforeseen system malfunctions.

DCC technology may also be applied directly to the feedwater heaters in a plant's feedwater train. A study, similar in nature and scope to this present study, can evaluate the potential benefits of using DCCs as feedwater heaters. 
TP-4514 


\subsection{Acknowledgments}

Efforts of Benjamin Shelpuk in initiating the task of looking at the use of direct contact condensers for utility applications are recognized. Continued interaction and encouragement offered by Gerald Nix, Larry Flowers, and Terry Penney are appreciated.

Valuable reviews of the work in progress were provided by John Bartz of the Electric Power Research Institute, Otakar Jonas of Jonas Inc., and John Burns of Stone and Webster Engineering Corporation.

Support received from Jim Green for carrying out the subcontract work is acknowledged. Early extensive testing of a variety of structured packings and the development of the detailed modeling capability at NREL were carried out under the DOE's Ocean Energy Technology Program. The in-house effort for the reported work was supported by the NREL Director's Discretionary Funds. 
TP-4514 


\subsection{References}

1. Bell, R. and Strauss, S.D., 1991, "Advancing Heat-Exchanger Reliability," Power, July, pp. 13-22.

2. Jonas, O., 1990, "Controlling Oxygen in Steam Generating Systems," Power, May, pp. 43-52.

3. Bell, R.J., Impagliazzo, A.M., and Mussalli, Y.G., 1982, "Failure-Cause Analysis Condenser and Associated Systems," Electric Power Research Institute, Report CS-2378, Volume 1, Palo Alto, CA.

4. 1988, Proceedings: Condenser Technology Symposium Electric Power Research Institute, Report CS-5942-SR, Palo Alto, CA.

5. Bell, R.J. and Nery, R.A., 1981, An Engineering Approach to a Cost-Effective Schedule for Condenser Cleaning, in Fossil Heat Rate Improvement Conference and Workshop, Electric Power Research Institute, Report CS-2180, Palo Alto, CA.

6. Tondi, D.M., 1988, Experience with the Use of $\mathrm{SF}_{6}$ to Locate Condenser Leakage in Power Plants, a paper in Ref.[4].

7. Bharathan, D., Parsons, B.K., and Althof, J.A., 1988, Direct-Contact Condensers for Open-Cycle OTEC Applications, Solar Energy Research Institute, Report SERI/ TR-252-3108, Golden, CO.

8. Heat Exchanger Design Handbook, 1984, Hemisphere Publishing Co., Chapter 3.7.,Washington, D.C.

9. D'Errico, P.A. and Burns, J.M., 1991, An Assessment of Direct Contact Condensers for Steam Power Plants, Stone and Webster Engineering Corporation, Report 19187.02-M(D)-1, Denver, CO.

10. Spencer, R.C., Cotton, K.C., and Cannon, C.N., 1974, A Method for Predicting the Performance of Steam Turbine Generators $16,500 \mathrm{~kW}$ and Larger, General Electric Publication GER-2007C, Schenectady, NY.

11. Heat Exchange Institute, 1984, Standards for Steam Surface Condensers, Eighth Edition, Cleveland, $\mathrm{OH}$.

12. Harris, L. and Bornstein, B., 1979, Consideration of Condenser Height Optimization of Power Plant Condensers, American Society of Mechanical Engineers, Paper 79-JPGC-Pwr-2, New York, NY.

13. Beckett, G., 1988, Computer Aided Design of a Modified Tube Layout for a Power Condenser, a paper in Ref.[4]. 


\begin{tabular}{|c|c|c|c|}
\hline Document Control Page & $\begin{array}{l}\text { 1. NREL Report No. } \\
\text { NREL/TP-254-4514 }\end{array}$ & $\begin{array}{l}\text { 2. NTIS Accession No. } \\
\text { DE92001191 }\end{array}$ & 3. Recipient's Accession No. \\
\hline \multirow{2}{*}{\multicolumn{3}{|c|}{$\begin{array}{l}\text { 4. Title and Subtitle } \\
\text { An Assessment of the Use of Direct Contact Condensers with Wet Cooling } \\
\text { Systems for Utility Steam Power Plants }\end{array}$}} & $\begin{array}{l}\text { 5. Publication Date } \\
\text { February } 1992\end{array}$ \\
\hline & & & 6. \\
\hline \multicolumn{3}{|c|}{$\begin{array}{l}\text { 7. Author(s) } \\
\text { Desikan Bharathan, Edward Hoo, Paul D'Errico }\end{array}$} & 8. Performing Organization Rept. No. \\
\hline \multirow{2}{*}{\multicolumn{3}{|c|}{$\begin{array}{l}\text { 9. Performing Organization Name and Address } \\
\text { National Renewable Energy Laboratory } \\
1617 \text { Cole Blvd. } \\
\text { Golden, CO } 80401\end{array}$}} & $\begin{array}{l}\text { 10. ProjecerTaskWork Unit No. } \\
25404000\end{array}$ \\
\hline & & & $\begin{array}{l}\text { 11. Contract (C) or Grant (G) No. } \\
\text { (C) } \\
\text { (G) }\end{array}$ \\
\hline \multirow{2}{*}{\multicolumn{3}{|c|}{$\begin{array}{l}\text { 12. Sponsoring Organization Name and Address } \\
\text { National Renewable Energy Laboratory } \\
1617 \text { Cole Blvd. } \\
\text { Golden, CO } 80401\end{array}$}} & $\begin{array}{l}\text { 13. Type of Report \& Period Covered } \\
\text { Technical Report }\end{array}$ \\
\hline & & & 14. \\
\hline \multicolumn{4}{|l|}{ 15. Supplementary Notes } \\
\hline \multicolumn{4}{|c|}{$\begin{array}{l}\text { Potential use of a direct contact condenser for disposing steam at the turbine exhaust of a utility power system using a wet } \\
\text { cooling system is investigated. To maintain condensate separate from the cooling water, a bank of plate heat exchangers is used. } \\
\text { In a case study for a nominal 130-MW, steam power plant, two heat rejection systems, one using a conventional surface } \\
\text { condenser and another using a direct contact condenser together with a set of plate heat exchangers are compared on the basis of } \\
\text { their performance, operation and maintenance, and system economics. Despite a higher inilial cost for the direct contact system, } \\
\text { the advantages it offers suggest that this system is viable both technically and economically. }\end{array}$} \\
\hline \multicolumn{4}{|c|}{$\begin{array}{l}\text { 17. Document Analysis } \\
\text { a. Descriptors } \\
\text { condensers; availability; reliability; direct contact condensers; steam power plants } \\
\text { b. Identifiers/Open-Ended Terms }\end{array}$} \\
\hline \multicolumn{4}{|l|}{$\begin{array}{l}\text { c. UC Categories } \\
350\end{array}$} \\
\hline \multirow{2}{*}{\multicolumn{2}{|c|}{$\begin{array}{l}\text { 18. Availability Statement } \\
\text { National Technical Information Service } \\
\text { U.S. Department of Commerce } \\
5285 \text { Port Royal Road } \\
\text { Springfield, VA } 22161\end{array}$}} & & $\begin{array}{l}\text { 19. No. of Pages } \\
40\end{array}$ \\
\hline & & & $\begin{array}{l}\text { 20. Price } \\
\text { A03 }\end{array}$ \\
\hline
\end{tabular}

Form No. 0069E (6-30-87) 